\title{
Effects of Melatonin-Soaked Seeds on Photosynthetic Pigment Contents and Antioxidant Enzyme Activities of Broadbean (Vicia faba) Seedlings
}

\author{
Piao Liu ${ }^{1, a}$, Cheng Chen ${ }^{2, b}$ and Lijin Lin ${ }^{3, c *}$ \\ ${ }^{1}$ College of Horticulture, Sichuan Agricultural University, Chengdu, Sichuan, China \\ ${ }^{2}$ College of Economics, Sichuan Agricultural University, Chengdu, Sichuan, China \\ ${ }^{3}$ Institute of Pomology and Olericulture, Sichuan Agricultural University, Chengdu, Sichuan, China \\ aliufei569@qq.com, b8521153@qq.com, '1lj800924@qq.com \\ *Corresponding author. Piao Liu and Cheng Chen contributed equally to this work.
}

\begin{abstract}
Keywords: Melatonin; Broadbean; Cadmium; Photosynthetic pigment; Antioxidant enzyme
Abstract: In order to discuss the melatonin (MT) on photosynthetic pigment contents and antioxidant enzyme activities of vegetables, broadbean (Vicia faba) seeds were soaked in five doses $(0,50,100,150$ and $200 \mu \mathrm{mol} / \mathrm{L})$ of $\mathrm{MT}$ and then planted in pots containing cadmium $(\mathrm{Cd})$ contaminated soil. The 50- and 100- $\mu \mathrm{mol} / \mathrm{L}$ MT doses had no significant effects on the contents of chlorophyll a, total chlorophyll and carotenoid in broadbean seedlings, while the 150- and $200-\mu \mathrm{mol} / \mathrm{L}$ MT doses increased them. MT also increased the activities of superoxide dismutase, peroxidase and catalase, and the contents of soluble protein in broadbean seedlings compared with their respective controls. Thus, MT could improve the resistance of broadbean seedlings to $\mathrm{Cd}$ stress.
\end{abstract}

\section{Introduction}

In recent years, soil heavy metal contamination has become increasingly serious. When soil is contaminated with heavy metals, it affects crop yield and quality, and may enter the food chain, which can affect human health [1]. In China, among the soil heavy metal contaminants, cadmium (Cd) occurs in the largest area [2]. Thus, it needs finding other methods to resolve heavy metal (especially $\mathrm{Cd}$ ) contamination while maintaining the existing agricultural production.

Broadbean (Vicia faba Linn) is an herb, in addition to being a good food, and the plant is also a good fertilizer [3]. In recent years, because of the increasing level of Cd contamination, the yield and quality of broadbean has been seriously affected [4]. In this research, the effects of Melatonin (MT) on photosynthetic pigment contents and antioxidant enzyme activities of broadbean seedlings were studied to determine whether MT can improve the resistance of broadbean seedlings to $\mathrm{Cd}$ stress.

\section{Materials and Methods}

Materials. Local varieties of broadbean grown in Chengdu, Sichuan Province, China were used in this study. The soil samples were fluvo-aquic soils, which were collected from the Chengdu Campus Farm of Sichuan Agricultural University (30 $42^{\prime}$ N, 103 $101^{\prime}$ E) in October 2015. The soil basic properties and its Cd content were described in Liu et al. (2015) [5]. Then, $0.5 \mathrm{~kg}$ of air-dried soil was placed into each polyethylene pot (10-cm high, 8 -cm diameter). $\mathrm{Cd}\left(\mathrm{CdCl}_{2} \cdot 2.5 \mathrm{H}_{2} \mathrm{O}\right)$ was added to the soil samples at a dose of $10 \mathrm{mg} / \mathrm{kg}$ according to [6]. The soil moisture was maintained at $80 \%$ of field capacity for one month.

Experimental Design. In November 2015, the seeds of broadbean were soaked in different doses $(0,50,100,150$ and $200 \mu \mathrm{mol} / \mathrm{L})$ of MT for $48 \mathrm{~h}$. A 50-mL solution soaked approximately 15 seeds. Then, the seeds were placed in an incubator to germinate at $26^{\circ} \mathrm{C}$ for $48 \mathrm{~h}$, and four uniform seeds with buds were transplanted into the prepared soil of each pot in the greenhouse of the Chengdu Campus Farm. Every treatment was replicated four times (four pots). We watered every day to keep the soil moist. When the broadbean seedlings had grown for one month (December 2015), the third upper mature leaves of broadbean seedlings were collected to determine the contents of chlorophyll 
$a$, chlorophyll $b$, total chlorophyll and carotenoid, the superoxide dismutase (SOD), peroxidase (POD) and catalase (CAT) activities and the content of soluble protein [7].

Statistical Analyses. Data were analyzed using SPSS 13.0 statistical software (IBM, Chicago, IL, USA).

\section{Results and Discussion}

Photosynthetic Pigment Contents in Broadbean Seedlings. Compared with the control, doses of 50 and $100 \mu \mathrm{mol} / \mathrm{L}$ MT had no significant effects on contents of chlorophyll $a$, total chlorophyll and carotenoid in broadbean seedlings, while doses of 150 and $200 \mu \mathrm{mol} / \mathrm{L}$ MT increased the contents (Table 1). When the doses of MT were 150 and $200 \mu \mathrm{mol} / \mathrm{L}$, compared with the control, the total chlorophyll contents increased by $6.53 \%$ and $9.20 \%$ respectively, and the contents of carotenoid increased by $5.77 \%$ and $9.62 \%$ respectively. However, the different MT concentrations had no significant effects on the chlorophyll $b$ contents of broadbean seedlings.

Table 1 Photosynthetic pigment contents in broadbean seedlings

\begin{tabular}{|c|c|c|c|c|}
\hline $\begin{array}{c}\text { Melatonin } \\
\text { concentrations } \\
(\mu \mathrm{mol} / \mathrm{L})\end{array}$ & $\begin{array}{c}\text { Chlorophyll } a \\
(\mathrm{mg} / \mathrm{g})\end{array}$ & $\begin{array}{c}\text { Chlorophyll } b \\
(\mathrm{mg} / \mathrm{g})\end{array}$ & $\begin{array}{c}\text { Total chlorophyll } \\
(\mathrm{mg} / \mathrm{g})\end{array}$ & $\begin{array}{c}\text { Carotenoid } \\
(\mathrm{mg} / \mathrm{g})\end{array}$ \\
\hline 0 & $2.86 \pm 0.04 \mathrm{c}$ & $0.511 \pm 0.017 \mathrm{a}$ & $3.37 \pm 0.06 \mathrm{c}$ & $1.04 \pm 0.02 \mathrm{c}$ \\
\hline 50 & $2.93 \pm 0.07 \mathrm{bc}$ & $0.528 \pm 0.031 \mathrm{a}$ & $3.46 \pm 0.10 \mathrm{bc}$ & $1.07 \pm 0.03 \mathrm{bc}$ \\
\hline 100 & $2.92 \pm 0.04 \mathrm{bc}$ & $0.572 \pm 0.066 \mathrm{a}$ & $3.49 \pm 0.11 \mathrm{bc}$ & $1.07 \pm 0.02 \mathrm{bc}$ \\
\hline 150 & $3.00 \pm 0.02 \mathrm{~b}$ & $0.587 \pm 0.026 \mathrm{a}$ & $3.59 \pm 0.01 \mathrm{ab}$ & $1.10 \pm 0.01 \mathrm{~b}$ \\
\hline 200 & $3.11 \pm 0.01 \mathrm{a}$ & $0.569 \pm 0.011 \mathrm{a}$ & $3.68 \pm 0.01 \mathrm{a}$ & $1.14 \pm 0.01 \mathrm{a}$ \\
\hline
\end{tabular}

Values are means $( \pm$ SE) of four replicate pots. Significant differences (indicated by different lowercase letters) within a column are based on a one-way analysis of variance with the least significant difference test $(p<0.05)$, and followed by the post-hoc test.

Antioxidant Enzyme Activities of Broadbean Seedlings. The $50-\mu \mathrm{mol} / \mathrm{L}$ MT dose had no significant effects on the SOD and POD activities of broadbean seedlings compared with the control, while the 100-, 150- and 200- $\mu \mathrm{mol} / \mathrm{L}$ MT doses increased the enzyme activity levels (Table 2). When the doses of MT were 100, 150 and $200 \mu \mathrm{mol} / \mathrm{L}$, compared with the control, the SOD activity of broadbean seedlings improved by $25.60 \%, 64.06 \%$ and $75.86 \%$ respectively, while the POD activity improved by $16.48 \%, 21.12 \%$ and $27.64 \%$ respectively. The different concentrations of MT improved the CAT activity of broadbean seedlings compared with the control, but there were no significant differences among the 50-, 100- and 150- $\mu \mathrm{mol} / \mathrm{L}$ MT doses. MT also increased the soluble protein contents of broadbean seedlings compared with the control, with the maximum occurring at the 200- $\mu \mathrm{mol} / \mathrm{L}$ MT dose. Thus, MT could increase the resistance of broadbean seedlings to Cd stress.

\section{Discussion}

MT, as an antioxidant, can prevent the degradation of chlorophyll [8] and protect the photosynthetic systems [9]. Under high-temperature stress, MT increases the chlorophyll content, the primary light energy conversion efficiency of cucumber seedlings; thereby, improving their photosynthetic capacity [10]. Other studies reported the same effects on plants under high-temperature stress [11] and nitrate stress [12]. In this study, 50 and $100 \mu \mathrm{mol} / \mathrm{L}$ of MT had no significant effects on the photosynthetic pigment content of broadbean seedlings, while 150 and $200 \mu \mathrm{mol} / \mathrm{L}$ of MT increased that the pigment content, which was not completely consistent with previous studies [10-12]. Thus, only higher concentrations of MT could promote photosynthetic pigment synthesis in broadbean, 
and the sensitivity of broadbean to MT was lower than that of other plants [10-12].

Under heavy metal stress, active oxygen is produced in plants, which can destroy their membrane system [13-14]. The exogenous MT can promote antioxidant protection in plant seeds and seedlings by chelating with metal ions [15-16]. The exogenous MT increases the CAT activity and soluble protein content in young rice buds under $\mathrm{Ni}$ stress [17] and also improves the activities of SOD, POD and CAT in rice seedlings under Cd stress [18]. In this experiment, $50 \mu \mathrm{mol} / \mathrm{L}$ of MT had no significant effects on the SOD and POD activities of broadbean seedlings, while 100-, 150- and $200-\mu \mathrm{mol} / \mathrm{L}$ MT doses improved their activities. The different concentrations of MT increased the CAT activity level and the soluble protein content of broadbean seedlings. These results were similar to those of previous studies [17-18], which might be related to MT's role as an antioxidant [19-20]. Thus, MT could improve the resistance of broadbean seedlings to $\mathrm{Cd}$ stress by increasing the antioxidant enzyme activity levels.

Table 2 Antioxidant enzyme activities of broadbean seedlings

\begin{tabular}{|c|c|c|c|c|}
\hline $\begin{array}{c}\text { Melatonin } \\
\text { concentrations } \\
(\mu \mathrm{mol} / \mathrm{L})\end{array}$ & $\begin{array}{c}\text { SOD activity } \\
(\mathrm{U} / \mathrm{g})\end{array}$ & $\begin{array}{c}\text { POD activity } \\
(\mathrm{U} / \mathrm{g})\end{array}$ & $\begin{array}{c}\text { CAT activity } \\
(\mathrm{U} / \mathrm{g})\end{array}$ & $\begin{array}{c}\text { Soluble protein } \\
\text { content } \\
(\mathrm{mg} / \mathrm{g})\end{array}$ \\
\hline 0 & $21.09 \pm 0.58 \mathrm{c}$ & $140.56 \pm 2.23 \mathrm{c}$ & $13.69 \pm 0.28 \mathrm{c}$ & $16.70 \pm 0.13 \mathrm{c}$ \\
\hline 50 & $24.61 \pm 2.68 \mathrm{bc}$ & $147.83 \pm 3.39 \mathrm{c}$ & $18.09 \pm 1.12 \mathrm{~b}$ & $18.03 \pm 0.19 \mathrm{~b}$ \\
\hline 100 & $26.49 \pm 1.15 \mathrm{~b}$ & $163.72 \pm 1.27 \mathrm{~b}$ & $19.43 \pm 1.04 \mathrm{~b}$ & $18.35 \pm 0.29 \mathrm{~b}$ \\
\hline 150 & $34.60 \pm 2.38 \mathrm{a}$ & $170.24 \pm 1.68 \mathrm{ab}$ & $21.23 \pm 1.61 \mathrm{~b}$ & $18.54 \pm 0.47 \mathrm{~b}$ \\
\hline 200 & $37.09 \pm 1.40 \mathrm{a}$ & $179.41 \pm 8.91 \mathrm{a}$ & $26.39 \pm 2.40 \mathrm{a}$ & $19.65 \pm 0.15 \mathrm{a}$ \\
\hline
\end{tabular}

Values are means $( \pm$ SE) of four replicate pots. Significant differences (indicated by different lowercase letters) within a column are based on a one-way analysis of variance with the least significant difference test $(p<0.05)$, and followed by the post-hoc test.

\section{Conclusions}

Under Cd stress, the 50- and 100- $\mu \mathrm{mol} / \mathrm{L}$ MT doses had no significant effects on the contents of chlorophyll a, total chlorophyll and carotenoid in broadbean seedlings, while the 150- and $200-\mu \mathrm{mol} / \mathrm{L}$ MT doses increased them. MT also increased the activities of superoxide dismutase, peroxidase and catalase, and the contents of soluble protein in broadbean seedlings compared with their respective controls. Thus, MT could improve the resistance of broadbean seedlings to $\mathrm{Cd}$ stress.

\section{Acknowledgements}

This work was financially supported by the Application Infrastructure Project of Science and Technology Department of Sichuan Province (2016JY0258).

\section{References}

[1] Y.J. Li: Environmental Problems and Countermeasures of Intensive Agriculture (China Agriculture Press, Beijing, China 2001).

[2] C.Y. Ma, D.J. Cai and H. Yan: Henan Chemical Industry Vol. 30 (2013), p. 17.

[3] Q.Q. Li, C. Wang, F. Wang and S.D. Ji: Rain Fed Crops Vol. 27 (2008), p. 56.

[4] Y. Li, J.J. Li and X.H. Wei: Acta Prataculturae Sinica Vol. 18 (2009), p. 186.

[5] Y. Liu, L. Lin, Q. Jin and X. Zhu: Environmental Progress \& Sustainable Energy Vol. 34 (2015), p. 663. 
[6] L. Lin, M. Liao, Y. Ren, L. Luo, X. Zhang, D. Yang and J. He: PLoS ONE Vol. 9 (2014), p. e114957.

[7] Z.B. Hao, J. Cang and Z. Xu: Plant Physiology Experiment (Harbin Institute of Technology Press, Harbin, China 2004).

[8] M.B. Arnao and J. Hernándezruiz: Journal of Pineal Research Vol. 46 (2009), p. 58.

[9] D. Lazár. S.J. Murch, M.J. Beilby and A.K. Sabah: Plant Signaling \& Behavior Vol. 8 (2013), p. e23279.

[10]X.D. Xu, Y. Sun, X.Q. Guo, B. Sun and J. Zhang: Acta Agriculturae Nucleatae Sinica Vol. 25 (2011), p. 179.

[11]F.E. Bian, Y.J. Sun, Y.J. Niu, Y.P. Du and H. Zhai: Plant Physiology Journal Vol. 53 (2017), p. 257.

[12] W.X. Wang: Effects of Exogenous Melatonin on Antioxidant System and Nitrogen Metabolism of Cucumber Seedlings under Nitrate Stress (Master Thesis, Northwest A \& F University, China 2015).

[13]F. Thévenod and W.K. Lee: Archives of Toxicology Vol. 87 (2013), p. 1743.

[14]A. Schützendübel and A. Polle: Journal of Experimental Botany Vol. 53 (2002), p. 1351.

[15]N. Susa, S. Ueno, Y. Furukawa, J. Ueda and M. Sugiyama: Toxicology and Applied Pharmacology Vol. 144 (1997), p. 377.

[16]M.M. Posmyk, H. Kuran, K. Marciniak and K.M. Janas: Journal of Pineal Research Vol. 45 (2008), p. 24.

[17] S.X. Liu, Y.Z. Huang, Z.J. Luo, Y.C. Huang and H. Jiang: Environmental Science Vol. 38 (2017), p. 1675.

[18] S.X. Liu, Y.Z. Huang, Z.J. Luo, Y.C. Huang, Q.L. Bao, P.P. Wang, B. Yuan and W.H. Li: Journal of Agro-environment science Vol. 35 (2016), p. 1034.

[19]R.J. Reiter and D.X. Tan: Annals of the New York Academy of Sciences Vol. 957 (2002), p. 341.

[20]R.J. Reiter, D.X. Tan, S. Burkhardt and L.C. Manchester: Nutrition Reviews Vol. 59 (2001), p. 286. 